\title{
FEDERALISM IN RUSSIA: CURRENT STATE AND EMERGING TRENDS
}

\author{
MARAT SALIKOV, \\ Ural State Law University (Yekaterinburg, Russia)
}

https://doi.org/10.21684/2412-2343-2020-7-4-127-152

The article considers the phenomenon of federal relations in modern Russia from a theoretical and normative point of view. Studying related categories, such as federalism, federation and federal system, the author comes to the conclusion that it is federal relations, which by their nature are purely legal relations, are the core of any federal system. It is the analysis of the dynamics of development of these relations that shows the viability of a particular federal system. Using the concept of systems theory, the author reveals the structure of federal relations, which includes their subjects, objects and content. In turn, the content of federal relations can be revealed using the principles of both the horizontal and the vertical separation of powers. In this regard, not only normative regulation (the Constitution, federal and regional laws), but also judicial practice are of great importance: namely, decisions of the Constitutional Court of the Russian Federation, which handed down a significant number of decisions revealing the essence of federal relations in specific cases and resolving existing problems. The development of the federal system, and, consequently, the actual federal relations can be traced in examples of an institutional and regulatory nature. Vivid examples of this development are structural changes in the federal system associated with the formation of a new constituent entity of the federation and the adoption of a new constituententity in the federation. Such examples have occurred in modern Russia, although in the case of the adoption of new entities in the current regulatory framework, certain problems are found that should be eliminated by making appropriate amendments to the law governing the procedure for such adoption. The COVID-19 pandemic, unfortunately, has affected virtually every nation in the world. The relationship between the federal center and the constituent entities of the federation in such an extraordinary situation has been affected too and has undergone certain changes. Their analysis cannot but lead to a correction of the normative regulation of federal relations in the event of similar situations in the future. Amendments to the Constitution of the Russian Federation have affected a large layer of public relations. Federal relations are no exception, since the "Federated Structure" section of the Constitution includes a number of rather interesting changes. 
Keywords: federal system; content of federal relations; Constitutional Court; constitutional amendments.

Recommended citation: Marat Salikov, Federalism in Russia: Current State and Emerging Trends, 7(4) BRICS Law Journal 127-152 (2020).

\section{Table of Contents}

\section{Introduction}

1. Meaning and Essence of Federal Relations

2. Subjects and Objects of Federal Relations

3. Content of Federal Relations Depending on Separation of Powers Doctrine

\subsection{The Content of Federal Relations in the Fields of Legislative and Executive Power}

3.2. The Content of Federal Relations in the Field of the Implementation of the Judiciary

4. Changes in the Russian Federation's Structure

4.1. Procedure for Admission to the Russian Federation of a New Constituent Entity

\subsection{Procedure for Formation of a New Constituent Entity of the Russian Federation}

\section{Contemporary Trends in Federal Relations Development}

5.1. The Impact of the Global COVID-19 Pandemic on Federal Relations

5.2. The Impact of the Constitutional Amendments on Federal Relations Conclusion

\section{Introduction}

In science, there are many definitions of the concept of system. Representatives of various sciences, including the social sciences, are involved in systems analysis. The broadest definition was given in due time by Ludwig von Bertalanffy, who defined the system as a complex of interacting elements:

We will call everything consisting of parts connected with each other a system.'

Берталанфи Л. фон. Общая теория систем - обзор проблем и результатов // Системные исследования. Ежегодник [Ludwig von Bertalanffy, General System Theory - Overview of Problems and Results in System Research. Yearbook] 30 (Moscow: Nauka, 1969). 
All systems can be divided into certain types. In science, there are many classifications of systems. We give one of them, given by I. Rodionov. According to this classification, systems should be subdivided according to specific criteria. So, according to their interaction with the external environment, systems are divided into open, closed and combined systems. By structure - simple, complex and large. By the nature of functions - specialized and multifunctional (universal). By the nature of development, they are stable and developing. According to the degree of organization - well organized and poorly organized (diffuse). By complexity of behavior - automatic, decisive, self-organizing, anticipating and transforming. By the nature of the relationship between the elements - deterministic and stochastic. By the nature of the management structure, they are centralized and decentralized. By purpose - production, management and maintenance. By content - real (material) and abstract (conceptual, ideal). In this case, real systems are divided into natural (natural systems) and artificial (man-made). The latter are created by mankind for their needs or are formed as a result of deliberate efforts. They, in turn, are divided into technical (technical and economic) and social (public). Social systems include various systems of human society. ${ }^{2}$

The federal system, being one of the social systems, is a complex structure, which, in our opinion, includes not only "simple," but also "complex" elements, namely, other systems. These include, for example, the political, legal, party, judicial, territorial, electoral systems, the system of state bodies, etc. Thus, if we follow this classification, then the federal systems existing in the world should be attributed to the number of real (material), artificial (man-made), social (public) systems.

Federal relations as internal relations between elements of the system are also included in it. Otherwise it would not be a system, but a simple set of elements. The system implies a synergistic effect arising from the interaction of all its elements. By analyzing the ideal structure of federal relations, including their subjects, objects and content, one can trace how a particular federal system actually functions, what problems it is experiencing and what solutions can be made at different stages of its development. The content of federal relations is the activity of their entities in the implementation of the subjects of competence and authority of the federation, its entities, their bodies and officials, as well as in the implementation of other constitutional provisions laid down in Ch. 3 of the Constitution of the Russian Federation "Federated Structure." The actual content of the relations under consideration can be seen in the analysis of the practice of the activities of certain subjects of federal relations. The latter can be considered from the point of view of the universal principle of the separation of powers, moreover, not only in horizontal (legislative, executive and judicial branches of government), but also in vertical (federal, regional and in some cases municipal levels of public authority) sections.

2 Родионов И.Б. Теория систем и системный анализ [I.B. Rodionov, Systems Theory and Systems Analysis] (Sep. 16, 2020), available at http://victor-safronov.ru/systems-analysis/lectures/rodionov/01.html. 
A study of a functioning federal system allows us to identify the pros and cons of both the system itself and the links that exist between its elements (federal relations proper) and between the system and the external environment. Systems analysis makes it possible to highlight the essential characteristics of the system and, in some cases, to develop recommendations for the correction of existing properties, improving its regulatory regulation. An even greater effect can be achieved if this kind of consideration is supplemented by a comparative study, i.e. a comparative analysis of federal systems, especially those of them that have a long history of functioning so that positive experiences can be transferred to Russian soil. ${ }^{3}$ Of course, this kind of borrowing should be undertaken only after careful research.

Federal relations connect all the elements of the federal system, ensure its stable functioning, make it possible to level out the shortcomings and problems that arise during its development, and also to perceive something positive that has been gained not only within the framework of the national federation, but also within the framework of foreign analogues of federal systems.

\section{Meaning and Essence of Federal Relations}

In the science of constitutional law, different categories are used to describe a specific form of government: federalism, federation, federal system, federal regime, federal model, etc.

The existing constructions, of course, are intended to indicate specific phenomena of the real structure of the federal state in one form or another and/or volume. At one time, we proposed a generalizing category - the federal structure. A federal structure is a combination of the most important federal relations characterizing the essence and basic characteristics of the current federal system of a given state, as well as the principles and mechanisms of its functioning, reflecting the dynamics of the development of federal relations in a given federation.

Closest to this category are federalism and the federal system. In our opinion, federalism can be defined as a harmonious concept or, more broadly, a doctrine that determines the nature of the interaction of various levels of public authorities on the basis of mutually agreed rules for achieving the goals facing this society and using ways and methods that are characteristic of the level of civilizational order. ${ }^{4}$

How to correlate federalism and the federal system? If federalism is, in fact, a theoretical model of federation, then the federal system is the practical

\footnotetext{
See, e.g., Panch Rishi dev Sharma, Comparative Federalism with Reference to Constitutional Machinery Failure (Emergency) in India and Pakistan, 4(2) BRICS Law Journal 71 (2017); Marianna Muravyeva, The Quest for Constitutionalism in South Africa, 3(1) BRICS Law Journal 138 (2016).

4 This definition was formulated by us back in 1998. Seе Саликов М.С. Сравнительный федерализм США и России [Marat S. Salikov, Comparative Federalism of the USA and Russia] (Yekaterinburg: Humanities University, 1998).
} 
implementation of this model with all the positive and negative aspects inherent in a given state at a given time. As is well known, each state has a constitution, a legal system, development plans, including federal relations. However, as practice shows, the design that is not always set out in the basic law works clearly and without flaws. Often there are some internal and/or external factors that do not allow to fully realize the potential that the constitutional legislator has laid down in the ideal model of federalism in a given state. The federal system allows us to understand the essence of the current situation with all the existing deviations, to trace the dynamics of the development of federal relations as a whole, or in a specific environment, and to predict the further development of the situation, as well as to formulate certain measures to stabilize the federal system, to make certain adjustments so that the existing ones' deviations could be eliminated as scheduled.

If we compare the federal structure with the federal system, then it should be noted that the category of the federal system, ${ }^{5}$ derived on the basis of systems analysis, allows one to identify all the elements of the system that exist in its complex relationships and the nature of its relationship with the external environment. The federal structure, firstly, includes a federal system, that is, it is wider in volume, and, secondly, it contains, in addition to the system itself, principles and mechanisms of functioning, as well as relations that are not purely federal, but are aimed at ensuring the "efficiency" of the system. For example, if a number of constituent entities of the federation are "sagging" in economic terms, the federal center can provide the necessary financial support in appropriate forms (subventions, loans, grants, writeoffs or installment payments ...), etc.

Of course, the main relations forming the federal system are federal relations, which include subjects, objects and content. In the legal literature, the term "federal relations" is often used. ${ }^{6}$ However, the doctrine does not contain sufficiently complete theoretical studies regarding the clarification of the essence of these relations, their structure, system, etc.

An analysis of the phenomenon of federal relations inevitably leads to the conclusion that these are legal relations. To conclude otherwise would mean a denial

5 Many authors use the term "federal system," moreover, not only to describe national and foreign systems, but also when conducting comparative studies. See, e.g., Daniel Halberstam, Federalism: Theory, Policy, Law in The Oxford Handbook of Comparative Constitutional Law 576 (M. Rosenfeld \& A. Sajy (eds.), Oxford: Oxford University Press, 2012); Todd A. Frommeyer, Power Sharing Treaties in Russia's Federal System, 21(1) Loyola of Los Angeles International and Comparative Law Review 1 (1999); Joseph F. Zimmerman, Contemporary American Federalism: The Growth of National Power (Westport, CT: Praeger Publishers, 1992); Ronald L. Watts, Comparing Federal Systems in the 1990s (Kingston: Queen's University, 1997); Daniel R. Mandelker et al., State and Local Government in a Federal System ( $3^{\text {rd }}$ ed., Charlottesville, VA: The Michie Company, 1990); Marat S. Salikov, Russian Federation Sub-National Constitutional Law (The Hague: Kluwer Law International, 2011).

6 Морозова А.С., Карасев А.Т. Проблемы совершенствования федеративных отношений в России: закономерности и отклонения // Конституционное и муниципальное право. 2015. № 10. Vol. 27-31 [Alexandra S. Morozova \& Anatoly T. Karasev, Problems of Improvement of Federal Relations in Russia: Regularities and Deviations, 10 Constitutional and Municipal Law 27 (2015)]. 
of the normative, and more often constitutionally, fixed nature of the federal state and those relations that are taking shape within the federal system. By analyzing the ideal structure of federal relations, including their subjects, objects and content, one can trace the means by which a certain federal system actually functions, the problems it is experiencing and the potential ways of solving them at different stages of its development.

\section{Subjects and Objects of Federal Relations}

The subjects of federal relations are participants in relations existing and arising between the federation and its subjects regarding the resolution of issues and problems that fall within the scope of their jurisdiction in accordance with the normatively established rules of this federal state. The system of subjects of federal relations includes the federation itself as an association of constituent entities as well as the constituent entities of the federation itself. However, it should be borne in mind that these public entities must be embodied in some form. Such forms are their organs. First of all, we are talking about government bodies: the head of state (the President of the Russian Federation), the highest officials of the constituent entities of the Russian Federation, the Federal Assembly of the Russian Federation, legislative (representative) government bodies of the constituent entities of the Russian Federation, and federal and regional courts. In addition, the subjects of federal relations include state bodies, for example, the Central Election Commission of the Russian Federation, election commissions of the constituent entities of the Russian Federation, the Audit Chamber of the Russian Federation and the audit chambers of the constituent entities of the Russian Federation. It seems that in some cases, the subjects of federal relations can also be municipalities and their bodies and officials. Such cases may be situations where separate state powers are delegated to the level of municipalities. When they are implemented, "municipal" participants become subjects of federal relations.

Objects of federal relations are objects or phenomena of reality, about which the subjects of these relations enter into them. Such objects can be most clearly seen, in particular, in the Constitution, namely in the norms that determine the scope of joint competence of the federation and its subjects within the federal system. So, in accordance with Article 72 of the Basic Law of the Russian Federation, the objects of federal relations include the rights and freedoms of man and citizen; minority rights; land, mineral resources, water and other natural resources; general principles of taxation and fees in the Russian Federation; general principles for organizing

\footnotetext{
More about this, see Саликов M.C. Субъекты, объекты и содержание федеративных отношений // Конституционно-правовой статус субъекта Российской Федерации: современное состояние и перспективы [Marat S. Salikov, Subjects, Objects and Content of Federal Relations in Constitutional and Legal Status of a Subject of the Russian Federation: Current Status and Prospects] (Tyumen: Tyumen State University Publ., 2016).
} 
a system of bodies of state power and local self-government; international and foreign economic relations of the constituent entities of the Russian Federation, etc.

The content of federal relations is the activity of their entities in the implementation of the subjects of competence and authority of the federation, its entities, their bodies and officials. Actually, these matters of competence and authority are contained in the Constitution of the Russian Federation, namely, in Articles 71-73, as well as in the legislation establishing the powers of the relevant government bodies and officials. The actual content of the relations under consideration can be seen in the analysis of the practice of the activities of certain subjects of federal relations. The latter can be considered from the point of view of the universal principle of the separation of powers, and not only in horizontal (legislative, executive and judicial branches of government), but also in vertical (federal, regional and, in some cases, municipal levels of public authorities) sections. ${ }^{8}$ We give some examples illustrating the content of federal relations in various fields.

\section{Content of Federal Relations Depending on Separation of Powers Doctrine}

\subsection{The Content of Federal Relations in the Fields of Legislative and Executive Power}

The content of federal relations in the field of legislative power

The federal legislative process provides for the right of the constituent entities of the Federation to express their own opinion on draft laws passed on subjects of joint jurisdiction. The Constitutional Court of the Russian Federation draws attention to this in its ruling of 23 April 2004. It states, in particular, that:

In the Russian Federation, as a state with a federal structure, its constituent entities are given the opportunity to present to the State Duma for discussion their position on the bill on the subject of joint jurisdiction [which] contributes to the effective implementation by the Federal Assembly of legislative activity in this area. Therefore, the establishment of a procedure providing for the submission by the State Duma of bills to the constituent entities of the Russian Federation, consideration of the proposals and comments made by them in the committees of the State Duma and the creation of conciliation commissions consisting of deputies of the State Duma and representatives of interested constituent entities of the Russian Federation, in cases where a significant number of constituent entities of the Russian Federation speaks

8 See, e.g., Maria A. Pechenskaya-Polishchuk, Issues of Improving Inter-Budget Relations Between the Region and the Federal Centre, 6(24) Economic and Social Changes: Facts, Trends, Forecast 156 (2012); Ruslan R. Sadyrtdinov, Interregional Trade Relations: The Republic of Tatarstan and Volga Federal District Regions of Russian Federation, 17(1) Journal of Economics and Economic Education Research 30 (2016). 
out against the bill as a whole or in a significant part of it; it is called upon to ensure the adoption of the federation "Act reflecting the interests of both the Russian Federation and its constituent entities."

However, the Court then notes that,

At the same time, such procedures should not impede the implementation of the powers of the Federal Assembly to adopt federal laws independently of the articles of joint jurisdiction arising from Articles 71 (clause a), 94 and 105 of the Constitution of the Russian Federation.

Of course, the federal parliament has the right and should adopt laws that are valid throughout the state, but Russia, in the form of state structure, is a federal state. And if the parliament of such a state is not obliged to take into account the opinion of the constituent entities of the federation (namely, this is indicated by the Court: "The approval procedure is aimed at achieving a mutually acceptable solution by coordinating the interests of all its participants. However, this does not imply the unconditional obligation of the State Duma to satisfy the requirements stated by the constituent entities of the Russian Federation."), then it is no different from the parliament of a unitary state. It seems that the constituent entities of the Russian Federation should have the right not only to state their position on this or that bill in the State Duma, but in a number of cases (if an appropriate mechanism is established, including the establishment of a minimum number of "dissenting" entities) and block its adoption.

Another decision (of 29 November 2006) of the Constitutional Court of the Russian Federation mediates the federal legislative process. In it, the Court considered the Regulation of the Government of the Russian Federation, according to paragraph 100 of which the draft law, submitted to the Government without financial and economic justification and other necessary materials, should be returned by the Government Office to the subject of the right of legislative initiative with the reasons why it is impossible to submit a conclusion. In its decision, the Court indicated that this norm

distorts the constitutional and legal nature of the conclusion of the Government of the Russian Federation on bills specified in part 3 of article 104 of the Constitution of the Russian Federation, since it essentially gives the character of a mandatory assessment of the financial and economic feasibility of a draft law, and the uncertainty of the concept of "financial and economic substantiation of the bill" may lead to inequality of subjects of the right of legislative initiative in the implementation of this right.

With regard to federal relations, this part of the resolution quite rightly notes that, 
In relation to the legislative (representative) bodies of the constituent entities of the Russian Federation, such inequality also means a violation of the equal rights of all constituent entities of the Russian Federation enshrined in article 5 (part 4) of the Constitution of the Russian Federation in their relationship with federal government bodies.

The content of federal relations in the field of executive power

The federal system assumes the existence of a well-functioning system for coordinating the activities of the executive authorities of the federation and its constituent entities. Here, it is vital to take into account the views of the constituent entities of the Federation when adopting acts of both the federal Government and federal executive bodies on subjects of joint jurisdiction, as well as on other issues relating to the interests of the constituent entities.

According to part 2 of Article 77 of the Constitution of the Russian Federation,

Within the jurisdiction of the Russian Federation and the powers of the Russian Federation on the subjects of joint jurisdiction of the Russian Federation and the constituent entities of the Russian Federation, the federal executive bodies and executive bodies of the constituent entities of the Russian Federation form a single system of executive power in the Russian Federation.

The Federal Constitutional Law "On the Government of the Russian Federation" repeats this norm and details it. In accordance with Article 43 of the said law:

The Government of the Russian Federation, within its powers, in order to ensure the combination of interests of the Russian Federation and the constituent entities of the Russian Federation in the joint jurisdiction of the Russian Federation and constituent entities of the Russian Federation in the field of executive power, coordinates the activities of the executive authorities of constituent entities of the Russian Federation.

Further in this article, a mechanism is established for the interaction of the Government of the Russian Federation and state authorities of the constituent entities of the Russian Federation, and it refers not only to executive bodies, but also to legislative bodies:

The Government of the Russian Federation shall consider proposals submitted to the Government of the Russian Federation in the prescribed manner in no more than one month legislative (representative) or executive bodies of state power of the constituent entities of the Russian Federation on matters within the jurisdiction of the Russian Federation and the joint 
jurisdiction of the Russian Federation and the Russian Federation, and reports to these bodies on the outcome of the proposals. The Government of the Russian Federation sends to the legislative (representative) and executive bodies of state power the constituent entities of the Russian Federation drafts of its decisions on the subjects of joint jurisdiction of the Russian Federation and constituent entities of the Russian Federation. The proposals of the legislative (representative) and executive bodies of state power of the constituent entities of the Russian Federation on such projects are subject to mandatory consideration by the Government of the Russian Federation.

Unfortunately, this does not give guarantees of taking into account the proposals of the constituent entities of the Federation, but only establishes the mandatory review of the federal Government.

The Basic Law provides for the possibility of exercising powers in the executive branch by both federal and regional bodies, and, if necessary, mutually transfer the exercise of part of their powers from one level of public authority to another. So, in accordance with parts 2 and 3 of Article 78 of the Constitution of the Russian Federation:

Federal executive bodies, by agreement with executive bodies of the constituent entities of the Russian Federation, may transfer to them the exercise of part of their powers, if this does not contradict the Constitution of the Russian Federation and federal laws; The executive bodies of the constituent entities of the Russian Federation, by agreement with the federal executive bodies, may transfer to them the exercise of part of their powers.

This is an example of the interaction of the federation and its constituent entities to increase the effectiveness of activities in areas of mutual interest and to solve the problems existing in them.

In this regard, the "Rostov case" (decision of the Constitutional Court of the Russian Federation of 2 July 2018) is of interest. In this case the Constitutional Court ruled that the disputed provisions of the Code of Administrative Offenses of the Russian Federation do not contradict the Constitution of the Russian Federation because by its normative content in the system of existing legal regulation it assumes that:

1. The conclusion of agreements on the transfer of the exercise of authority to draw up protocols on administrative offenses provided for by the laws of the constituent entities of the Russian Federation that infringe on public order and public safety is aimed at ensuring that the officials of the Department of Internal Affairs (police) ensure a balanced combination of interests of the federal and regional administrative bodies forming the unified system of executive power of the Russian Federation, meeting the tasks of effective administrative legal protection of the rights and freedoms of citizens; 
2. The initiative to conclude such agreements should come from the executive bodies of the constituent entities of the Russian Federation, which cannot be forced to sign them on unacceptable organizational, legal, financial or other conditions, and the federal executive bodies are not entitled to arbitrarily refuse to conclude the executive bodies of the constituent entities of the Russian Federation in cases when the draft relevant agreements meet the requirements established by federal laws and the laws of the constituent entities of the Russian Federation adopted in accordance with them; and

3. The officials of the police department (police) are obliged, within the framework of the powers vested in them by the Code of Administrative Offenses of the Russian Federation and the Federal Law "On Police," to provide assistance in bringing to justice those who commit administrative offenses provided for by the laws of the Russian Federation that infringe on general order and common safety even in the absence of relevant agreements concluded between the executive bodies of the constituent entities of the Russian Federation and the Ministry of Internal Affairs of the Russian Federation.

\subsection{The Content of Federal Relations in the Field of the Implementation of} the Judiciary

Considering this area, we can talk about judicial federalism, which we understand as the totality of the legal positions of the judicial body that performs the functions of a "constitutional regulator" (e.g. the U.S. Supreme Court or the Constitutional Court of the Russian Federation) regarding federal relations (as opposed to the ideas presented in the doctrine on judicial federalism as a system of the judiciary in a federal state). Thus, analyzing the decisions of the Constitutional Court of the Russian Federation, one can see how and when the positions of the federal center are strengthened, and the positions of the constituent entities of the Federation, respectively, are weakened, and vice versa. As examples, some decisions of the Constitutional Court of the Russian Federation can be cited.

\section{Examples of "pro-federal" decisions}

- The decision on the "case for the appointment of governors" (decision of 21 December 2005), in which the Court recognized the constitutional provision abrogating direct elections of the highest officials of the Federation. In this decision, it seems to us that the Court should have more clearly substantiated the need for a diametrical change in its legal position, as formulated in another decision.

-The decision on the "case of the Baltic Republican Party" (decision of 1 February 2005), in which the Court recognized the constitutional provision establishing a ban on the existence of political parties of the Russian Federation. Here, the Court's argumentation is based on hypothetical assumptions, which, in its opinion, will necessarily take place if the impugned norms are recognized as constitutional. As the Court pointed out, 
The creation of regional political parties - insofar as they would seek to uphold primarily their purely regional and local interests - could violate the state integrity and unity of the system of state power as the basis of Russia's federal structure.

It seems to us that the federation is precisely that form of government that presupposes the possibility and even the need for the functioning of political parties within individual entities, since they could reflect the urgent needs of certain regions. Of course, the regional branches of federal political parties should also work in the constituent entities of the Federation and compete with all political forces (including the regional political component) in a fair and law-based struggle.

- In another decision, in the "case of the judicial system of the constituent entities of the Russian Federation" (decision of 6 March 2003), the Court denied the regions of the Federation the right to have their own judicial systems. In our opinion, for a federal state, if it really considers itself as such, the presence of a judicial system in the constituent entities is, in fact, mandatory. Other federations have courts of land (states, cantons ...), i.e. regional judicial systems. It is different with us. Unfortunately, the Constitutional Court, not sufficiently substantiating its findings, denies the right of the subject of the Russian Federation to have its own judicial system. It seems that the presence of a single judicial system and, accordingly, the absence of regional judicial systems denies the universality of the principle realized in Article 10 of the Constitution of the Russian Federation.

- Of particular interest are the relations of the judicial bodies of the federation and the constituent entities of the federation. Here, a vivid example is the decision on the "Chelyabinsk case" (decision of 2 December 2013), in which the Constitutional Court of the Russian Federation recognized the constitutional norm of the regional law as previously recognized by the Charter Court of the Chelyabinsk Region as inadequate to its Charter and, accordingly, has lost force. Later in March 2014, the Legislative Assembly of the Chelyabinsk region abolished the Charter Court of the region.

Examples of "pro-regional" solutions

- Decision in the case of interpretation of part 2 of Article 137 of the Constitution of the Russian Federation (decision of 28 November 1995). In this decision the Constitutional Court established that a change in the name of a constituent entity of the Russian Federation is the exclusive prerogative of the entity of the Russian Federation, and the introduction into Article 65 of the Constitution of the new name of the entity of the Russian Federation is the responsibility of the head of state, i.e. the President of the Russian Federation.

- In the decision on the "Tatarstan case" (decision of 13 March 1992), the Constitutional Court noted that the subject of the Russian Federation is entitled to determine the procedure for conducting a regional referendum.

- In the "case of municipal qualifications" (decision of 24 December 2012), the Constitutional Court of the Russian Federation established that the constituent 
entities of the Russian Federation have the right to determine the model for the election of their highest officials (direct election, or empowerment by the regional parliament).

- The decision in the "case on guarantees of the activities of deputies of the regional parliament" (decision of 5 April 2013) recognized the constituent entities of the Russian Federation the right to establish a lump-sum payment to the deputies of the legislative (representative) state authority of the subject of the Russian Federation, carrying out parliamentary activities on a professional permanent basis, upon termination of their powers.

As can be seen, the constitutional-legal (including judicial-legal) regulation of federal relations is aimed at the situation when their subjects operate in an ordinary mode. However, extraordinary cases also occur, i.e. when the subjects of these relations go beyond the framework outlined by the legislator. First of all, we are talking about the constituent entities of the Russian Federation (although the federal center should be responsible in case of violations on its part). In such cases, the mechanism of federal intervention in the affairs of the constituent entities of the Russian Federation should be included. At present, individual measures of federal intervention are established by the Federal Law “On General Principles of Organization of Legislative (Representative) and Executive Bodies of State Power of the Constituent Entities of the Russian Federation." These measures include: the dissolution of the legislative (representative) state authority of the constituent entity of the Russian Federation, the removal from office of a senior official of the constituent entity of the Russian Federation, the introduction of a temporary financial administration in the constituent entity of the Russian Federation, the temporary assignment of certain powers of the state authority of the constituent entity of the Russian Federation to federal government bodies and/or to officials appointed by federal government bodies. It seems, however, that the regulation of such measures does not fully fit into the subject of this law, whose task is to establish general principles for the organization of regional legislative and executive bodies of state power. In our opinion, the adoption of a separate federal law "On Federal Intervention in the Affairs of the constituent entities of the Russian Federation" is necessary, and the Constitution should be supplemented in the form of an article devoted to this institution and referring to the law that would establish the regime of such interference, its measures and procedure for their implementation.

An example of the implementation of federal intervention measures is the "Chechen conflict" (although at that time there was no regulation of this kind of relationship). The Constitutional Court of the Russian Federation in the decision on the "Chechen case" (decision of 31 July 1995), as is known, recognized the contested decree of the President of the Russian Federation as relevant to the Constitution.

Given that at present many federal laws directly allow the possibility of concretizing the mechanisms for the implementation of certain constitutional rights 
and freedoms in the legislation of the constituent entities of the Russian Federation, we can give an example of a decision on the "case of public events" (decision of 14 February 2013). In accordance with the Federal Law "On Meetings, Meetings, Demonstrations, Processions and Pickets," the law of the constituent entity of the Federation additionally defines the places where public events are prohibited. In addition, the executive authorities of the constituent entities of the Russian Federation are empowered to determine specially designated or adapted places for holding peaceful meetings (part 1.1 of the said law).

Assessing the constitutionality of the last of the above provisions, the Constitutional Court of the Russian Federation came to the conclusion that the constituent entities of the Russian Federation have the opportunity, along with the basic guarantees of the rights of citizens enshrined in federal law, to

establish additional guarantees of these rights in their law or other normative legal act aimed at specifying them, the creation of additional mechanisms for their implementation, taking into account regional peculiarities (conditions) and observing constitutional requirements on the non-contradiction of the laws of the constituent entities of the Russian Federation to federal laws and on the inadmissibility of restricting the rights and freedoms of man and citizen in a form other than federal law.

The Court emphasized the inadmissibility of the introduction by regional regulatory legal acts of procedures and conditions that distort the "very essence of certain constitutional rights" and reduce the "level of their federal guarantees."

For any system, not only the constituent elements themselves are important, but also their interconnections and interaction. The federal system also cannot function effectively without established connections and interaction within itself. It is they that personify the federal relations taking shape between their subjects. Deep knowledge and understanding of the processes occurring in the federal system, high-quality legal regulation of the status of subjects of federal relations, as well as the possibility of their correction, if necessary, is the key to the strength of the federation as a complex, but nonetheless, single state.

\section{Changes in the Russian Federation's Structure}

\subsection{Procedure for Admission to the Russian Federation of a New Constituent Entity}

The Constitution of the Russian Federation in Article 137 provides for the possibility of adopting a new subject(s) into the Federation. Federal Constitutional Law of 17 December 2001 No. 6-FKZ "On the Procedure for Admitting to the Russian Federation and Formation of a New Constituent Entity of the Russian Federation" 
adopted in the development of this constitutional norm, regulates in detail the entire procedure for admission to the Russian Federation. In accordance with the said law, when admitting a new entity to the Federation (as well as when forming a new entity in its composition), the state interests of the Federation, the principles of its federal structure, human and civil rights and freedoms must be observed, and the historical, economic and cultural ties of the actors, and their socio-economic opportunities, taken into account.

The law provides that the initiator of the proposal for admission to the Russian Federation as a new entity is a foreign state, which, if a positive decision is received from the Russian state, enters into an international agreement with it. Within the framework of the agreement, issues related to the name and status of the new constituent entity of the Russian Federation, the procedure for acquiring Russian citizenship and the full distribution of the legal status of a citizen of the Russian Federation should be settled. Other legal aspects are also discussed, including the functioning of state authorities and local self-government of a foreign state on the territory of a new subject of the Russian Federation.

An international treaty may establish a transition period during which a new entity must be integrated into the economic, financial, credit and legal systems of Russia, as well as into the system of government bodies of the Russian Federation. On certain issues related to the admission to Russia as a new subject of a foreign state or part thereof, special protocols may be signed, subject to ratification simultaneously with the ratification of an international treaty.

After signing the international treaty, the President of Russia addresses the Constitutional Court of Russia with a request to verify the constitutionality of this international treaty. The next stage is the introduction into parliament of an international treaty for ratification and a draft federal constitutional law on the adoption of a new entity into the Russian Federation.

In the case of adoption and entry into force of these laws, amendments should be made to part 1 of Article 65 of the Constitution of the Russian Federation, which determines its composition. These changes are made on the basis of the federal constitutional law on the adoption of a new entity into the Russian Federation and are taken into account when reprinting the text of the Constitution of the Russian Federation.

The Republic of Crimea can serve as an example of the adoption of a new entity into the Russian Federation. As is well known, after the adoption of the Declaration of Independence of the Autonomous Republic of Crimea and the City of Sevastopol and the recognition by the Russian Federation of the "Republic of Crimea in Which the City of Sevastopol Has a Special Status," taking into account the will of the peoples of Crimea at the Crimean referendum on 16 March 2014, an international agreement was concluded between the Russian Federation and the Republic of Crimea on the admission to the Russian Federation of the Republic of Crimea and the formation 
in the Russian Federation of new entities, which was ratified by the chambers of the Federal Assembly RF and recognized by the Constitutional Court of the Russian Federation in accordance with the Constitution of the Russian Federation. Given that the Constitutional Court decides exclusively on issues of law, it did not assess the political feasibility of concluding this international treaty, recognizing its compliance with the Constitution of the Russian Federation in terms of content, in form, in order of signing, conclusion, adoption, publication and enforcement, from the point of view of the separation of state power established by the Constitution of the Russian Federation into legislative, executive and judicial, from the point of view established by the Constitution of the Russian Federation the distribution of powers between the federal bodies of state power, in terms of distribution of powers between the authorities of the Russian Federation and bodies of state power of constituent entities of the Russian Federation established by the Constitution, Federal and other treaties on the delimitation of powers.

On 21 March 2014, Federal Constitutional Law No. 6-FKZ "On the Admission to the Russian Federation and the Formation of New Constituent Entities of the Russian Federation - the Republic of Crimea and the City of Federal Significance Sevastopol" was adopted. Based on this law in Article 65 of the Constitution of the Russian Federation, the relevant changes were introduced.

Thus, at the moment, the Russian Federation includes 85 constituent entities: 22 republics, 9 territories, 46 regions, 3 cities of federal significance, 1 autonomous region and 4 autonomous districts.

Analyzing the first experience of the use of the Federal Law"On the Procedure for Admitting to the Russian Federation and Formation of a New Subject of the Russian Federation" regarding the adoption of new constituent entities into the Russian Federation, it should be noted that during its practical implementation there were known discrepancies. For example, the law provides that the completion of the procedures for both formation and adoption of a new entity must be formalized by the relevant federal constitutional law. Nevertheless, as is known, the adoption and formation of new entities within the Russian Federation in 2014 was formalized by one law - "On the Admission to the Russian Federation and the Formation of New Entities of the Russian Federation - the Republic of Crimea and the City of Federal Significance of Sevastopol." Thus, the legislator, in fact, combined the two procedures into one. This, among other things, allowed the legislator to solve another problem, namely, the transformation of the city into a city of federal significance. In this case, we are not talking about changing the status of the subject, since Sevastopol was not a subject of the Russian Federation (although in the Soviet period it was a city of republican subordination). As we can see, this violates the procedure established in the law for the adoption of a new entity(ies) into the Russian Federation. Indeed, the law establishing these procedures directly states that the result of all necessary measures for formation or adoption of a new subject must be the corresponding law - either on formation or 
on the adoption of a new subject. Thus, there is an obvious contradiction. However, taking into account the rather acute period during which the legislator was forced to make decisions that are quite important for the country, this "procedural economy" (combining the two procedures into one) seems quite justified. Moreover, the legislator himself has the right to both establish and change the "rules of the game."

The Constitutional Court noted in its decision of 19 March 2014 that:

The Treaty in question provides in Article 2 and a number of other articles for the combination of the procedures for admitting the Republic of Crimea to the Russian Federation and formation - as a consequence of this adoption - in the Russian Federation new entities of the Russian Federation - the Republic of Crimea and cities of federal significance Sevastopol. In accordance with Articles 5 (parts 1, 2 and 3) and 65 (part 2) of the Constitution of the Russian Federation, the adoption on the basis of the Treaty of the Republic of Crimea under consideration in the Russian Federation with the simultaneous formation of two new constituent entities of the Russian Federation - the Republic of Crimea and the city of federal significance Sevastopol should be implemented by establishing the features of this combined procedure in the federal constitutional law on the adoption of the Republic of Crimea to the Russian Federation.

As can be seen, the Court points to the need to "establish the features of the combined procedure" in the "special" law, i.e. in the law mediating the adoption of a specific subject, in this case, the Republic of Crimea. It seems, however, that subsequently it is necessary to make appropriate adjustments to the "general" law, which establishes the procedural rules for the formation and adoption of new entities. In particular, it should consolidate the right of the legislator, if necessary, to formalize changes in the composition of the Federation in the forms of formation and adoption of a new subject(s) by one law.

\subsection{Procedure for Formation of a New Constituent Entity of the Russian Federation}

In accordance with Article 137 of the Constitution of the Russian Federation, the composition of the Russian Federation can also be changed by the formation of a new constituent entity of the Russian Federation. The procedure for that is regulated by the above-mentioned Federal Constitutional Law of 17 December 2001 No. 6-FKZ"On the Procedure for Admitting to the Russian Federation and Formation of a New Constituent Entity of the Russian Federation." In accordance with this law, when forming in its composition a new constituent entity, the state interests of the Federation, the principles of its federal structure, human and civil rights and freedoms must be observed, as well as the historical, economic and cultural ties of the constituent entities, and their socio-economic capabilities. 
The procedure for the formation of a new constituent entity in the Russian Federation provides for a change in the composition of the constituent entities of the Russian Federation as a result of the merger of two or more neighboring entities. The formation of a new entity may entail the cessation of the existence of entities whose territories are to be merged. The initiative to form a new entity belongs to the constituent entities of the Russian Federation in whose territories it is being formed. The proposal on the formation of a new subject is sent to the President of the Russian Federation, who notifies the chambers of the Federal Assembly of the Russian Federation about it, the Government of the Russian Federation and, if necessary, conducts appropriate consultations with them. This proposal should be justified and contain the proposed name, status and boundaries of the new entity, a forecast of the socio-economic and other consequences associated with the formation of a new entity within the Federation, and also contain a number of supporting materials, including proposals for the succession of the new entity in relation to the property of interested constituent entities in relations with state authorities of the Federation, other constituent entities; proposals for amendments and additions to the federal law on the federal budget for the current year in connection with the formation of a new entity; information on the estimated dates for the referenda of interested parties, etc.

The issue of the formation of a new constituent entity is subject to referenda of interested entities and should be approved in all entities where a referendum is held. After receiving official data on the results of referenda, the President of the Russian Federation submits to the State Duma a draft federal constitutional law on the formation of a new constituent entity in the Russian Federation. The project should contain provisions defining the name, status and boundaries of the new entity, provisions on the termination of the existence of the entity (entities), if provided for by the merger plan, as well as provisions establishing the time frame within which the following issues should be resolved: the formation of public authorities of the new constituent entity; the making of amendments and additions to the federal law on the federal budget for the current year, if the formation of a new entity involves the redistribution of budget funds of the current year; the functioning of the territorial bodies of federal executive bodies and federal courts in the territory of the new entity; action of laws and other regulatory legal acts of interested entities in the territory of a new entity, etc.

After the adoption of the federal constitutional law on the formation in the Russian Federation of a new entity, amendments are made to part 1 of Article 65 of the Constitution of the Russian Federation, determining its composition.

At the time the Constitution of the Russian Federation entered into force in 1993, it included 89 entities: 21 republics, 6 territories, 49 regions, 2 cities of federal significance, 1 autonomous region and 10 autonomous districts. The process of unification of the constituent entities of the Federation, which took place in 2004- 
2008 , reduced their number by combining the territories, regions and their constituent autonomous districts to 83 . In all these cases, the relevant federal constitutional laws were adopted in accordance with the requirements of the Constitution of the Russian Federation.

So, from 1 December 2005, as a result of the unification of the Perm Region and the Komi-Permyak Autonomous District, the Perm Territory was formed; from 1 January 2007, as a result of the merger of the Krasnoyarsk Territory, the Taimyr (Dolgan-Nenets) Autonomous District and the Evenki Autonomous District - the Krasnoyarsk Territory; from 1 July 2007, as a result of the merger of the Kamchatka region and the Koryak Autonomous District - the Kamchatka Territory; from 1 January 2008, as a result of the merger of the Irkutsk region and the Ust-Orda Buryat Autonomous District - the Irkutsk Region; since 1 March 2008, as a result of the merger of the Chita region and the Aginsky Buryat Autonomous District - Zabaikal Territory.

The Federal Law "On the Procedure for Admitting to the Russian Federation and Formation of a New Constituent Entity of the Russian Federation" as part of the Russian Federation stipulates that the formation of a new constituent entity within the Russian Federation can take place only in the form of a combination of two or more entities, although the Constitution does not stipulate specific forms, the application of which may result in a new entity of the Federation appearing. For example, in the history of Russian federalism there has been a case of the division of one subject into two (the Chechen-Ingush Republic was divided into the Chechen and Ingush republics). Does this mean that the said law is contrary to the Constitution? It seems that the state in the person of the legislator has the right to determine the strategy and tactics in the field of federal construction, namely to determine specific forms of transformation of the federal system, in particular, changing the composition of the Federation at each given historical segment. At this stage, it is obvious that an increase in the number of constituent entities is hardly justified from many points of view. In this regard, the legislator has established that the formation of new entities can be carried out only in the form of an association. In the future, when specific historical conditions change and the need arises for the use of other forms, in particular separation, they can be provided for by the legislator.

The practice of changing the constitutional and legal status of constituent entities of the Russian Federation is still absent. To date, the federal constitutional law provided for by the Constitution of the Russian Federation, designed to regulate the procedure for such a change, has not been adopted. Nevertheless, we can talk about a peculiar transformation of the constitutional legal status of the constituent entities of the Russian Federation in situations of actual joining of one constituent entity of another constituent entity (although the legislator does not recognize this form of formation of a new constituent de jure, it exists de facto). Examples are the Perm Region, which was essentially transformed into the Perm Territory after the Komi-Permyak Autonomous District was annexed to it; the Kamchatka Region, 
which became the Kamchatka Territory after the Koryak Autonomous District was annexed; and the Chita Region, now called the Zabaikal Territory as a result of the takeover of the Aginsky Buryat Autonomous District. In all these cases, the regions, in fact, were transformed into territories.

In May of this year (2020), the acting governors of the Arkhangelsk Region and the Nenets Autonomous District signed a memorandum of intent to create a single entity of the Federation. It was assumed that a referendum on unification would be held before the year's end. However, the merger process was interrupted two weeks after the signing of the memorandum. The fact is that the local population of the Nenets Autonomous District came out sharply against the association. Evidence of this was apparent in public events in the district's administrative center Naryan-Mare such as pickets, collection of signatures against the association, etc. The reason for the negative attitude of the population of the district is their dissatisfaction with the distribution of funds between the district and the region. Residents of the district believe that

depriving a district of a constituent entity's status means a reduction in power and budget structures, loss of work and income by many residents, a reduction in investments in social infrastructure, and an increase in all kinds of costs associated with the need to travel to Arkhangelsk for many reasons. ${ }^{9}$

Given this situation, the political unification of the regions was postponed; instead, a joint program for the economic development of the regions will be developed. The authorities intend to return to the question of unification of regions after its implementation.

\section{Contemporary Trends in Federal Relations Development}

\subsection{The Impact of the Global COVID-19 Pandemic on Federal Relations}

The Russian federal system has always been considered quite centralized. If one compares it, say, with the American federal system, one can see the obvious differences, which lie in the greater freedom of the states. This is due to historical preconditions that led to the formation of the Confederation first, and then to its transformation into a federation. At the same time, federal relations in Russia did not remain without a certain influence of events that shocked mankind this year. This refers to the COVID-19 pandemic. The fact is that, given the huge size of the country, as well as the different parameters of infection with this disease in the constituent

Винокуров А., Литвинова М., Кадик Л. Необъединяемый автономный округ: Как Архангельская область не стала супер-регионом // Коммерсантъ. 31 мая 2020 г. [Andrey Vinokurov et al., Unified Autonomous Okrug: How the Arkhangelsk Region Did Not Become a Super-Region, Kommersant, 31 May 2020] (Sep. 16, 2020), available at https://www.kommersant.ru/doc/4364004. 
entities of the Federation, its leadership in the person of the head of state could not but delegate certain powers to the regional level, although these powers are exercised by the federal authorities in ordinary situations.

So, despite the fact that the possibility of vesting the highest official of a constituent entity of the Russian Federation with additional powers by a presidential decree is not directly provided, by decree of the President of the Russian Federation of 2 April 2020 No. 239 "On Measures to Ensure Sanitary and Epidemiological Welfare of the Population in the Russian Federation in Due to the Spread of a New Coronavirus Infection (COVID-19)," authorities of the constituent entities were given additional powers to develop and implement additional powers to develop and implement a set of restrictive and other measures.

Later, namely on 11 May 2020, Presidential Decree No. 316 was adopted "On Determining the Procedure for Extending the Measures to Ensure Sanitary and Epidemiological Welfare of the Population in the Constituent Entities of the Russian Federation in Connection with the Spread of a New Coronavirus Infection (COVID-19)." By this Decree, the heads of the regions were instructed to determine the territories on which restrictive measures could be extended if necessary, the specifics on which making such decisions were established, and a list of organizations which were not subject to these restrictions. Among them are hospitals, pharmacies, convenience stores, continuously operating organizations and banks.

It seems that in these conditions such a delegation of powers is justified. At the same time, by providing additional powers to the highest officials of the constituent entities, control over their implementation remained in the jurisdiction of the federation. In connection with the stabilization of the pandemic and even its weakening in a number of regions, their highest officials began to mitigate restrictive measures. But in this situation, the federal government, in fact, regained its regulatory role and established certain rules in this area. Thus, on 16 May 2020, the Government of the Russian Federation adopted Regulation No. 694"On the Procedure for Coordinating Draft Decisions of Highest Officials (Heads of the Highest Executive Bodies of State Power) of the Constituent Entities of the Russian Federation on Suspension (Limitation, Including by Determining the Characteristics of the Operating Mode, Number of Employees) Activities Located on the Territory of Certain Organizations and Individual Entrepreneurs Located Within the Boundaries of the Respective Constituent Entity of the Russian Federation." This Regulation approved the Rules for coordination of such actions of regional authorities with federal departments. Such departments include the Ministry of Economic Development of the Russian Federation, the Federal Service for Supervision of Consumer Rights Protection and Human Well-Being, and the Ministry of Finance of the Russian Federation.

It should be noted that the federal authorities are taking actions to support the regions in this difficult situation. For example, it was decided to adjust the schedule for their payments on budget loans. Under Regulation of the Government of the 
Russian Federation of 30 April 2020 No. 619 in 2020, the regions are completely exempted from paying off debt. In 2021-2024, they will pay 5\% of the debt annually; in 2025-2029 they will pay the balance in equal parts with the possibility of early repayment. Funds that will be released in 2020 can be used by entities to eliminate the consequences of the spread of the coronavirus infection, as well as to compensate for the reduction in tax and non-tax revenues. This will ensure the stability of regional budgets in the face of a difficult socio-economic situation.

\subsection{The Impact of the Constitutional Amendments on Federal Relations}

As is well known, recently the federal Constitution has been amended significantly. Let us consider which amendments affect federal relations.

Now the Constitution in Article 67 provides for the creation of so-called federal territories. The organization of public authority in these federal territories will be established by federal law. The status and purpose of such territories is not yet clear, but it is assumed that it is the federal authorities that will determine which territories should be separated from the relevant entities and made directly subordinate to the federation. Most likely, these will be some nature reserves, natural parks of national importance, as well as, possibly, objects related to the defense and security of the state.

A new norm has appeared (part 2.1 of Art. 67), according to which the Russian Federation ensures the protection of its sovereignty and territorial integrity. Actions (with the exception of delimitation, demarcation and re-demarcation of the state border of the Russian Federation with neighboring states) aimed at alienating part of the territory of the Russian Federation, as well as calls for such actions, are not allowed. The emergence of this norm is due to the existing claims of some states against Russia, for example, Japan's demands to transfer the so-called "northern territories" to it, namely a number of the Kuril Islands. According to the authors of this amendment, this constitutional provision will ensure the territorial integrity of the state.

A new article appeared in the Fundamental Law (Art. 67.1), according to which the Russian Federation, united by a thousand-year history, preserving the memory of ancestors who transmitted to us ideals and faith in God, as well as continuity in the development of the Russian state, recognizes the historically established state unity. As one can see, this rule is also aimed at maintaining the unity of the state. However, when discussing its content before the All-Russian vote on amendments, there were opinions that it contradicted the principles of a secular state, enshrined in the first chapter of the Constitution, as it allows the mention of God, which has never happened before.

The amendment concerning the state language seems quite interesting (Art. 68). The Constitution enshrined Russian as a state language before this amendment. But now its essential characteristic is added. The state language is defined here as the language of a state-forming people, a member of the multinational union of equal peoples of the Russian Federation. That is, it speaks of the people of all of Russia, 
which is called state-forming, and of the peoples inhabiting the Russian Federation, which are defined as equal, which is important, including for federal relations.

An addition made to Article 69 of the Constitution continues this theme. According to this amendment, the state protects the cultural identity of all the peoples and ethnic communities of the Russian Federation, and guarantees the preservation of ethnocultural and linguistic diversity. Thus, here, in essence, the Federation's duty to ensure the existing ethnocultural and linguistic diversity is formulated, which also seems to be extremely important.

Article 70 of the Constitution established that the capital of the Russian Federation is the city of Moscow. However, now the article is supplemented by the provision according to which the place of permanent residence of individual federal bodies may be another city defined by federal constitutional law. That is, by its law, a federation can establish a city other than Moscow where individual federal bodies may be located. Such practice already exists. So, the federal Constitutional Court was once moved from Moscow to St. Petersburg, which was enshrined in the federal constitutional law "On the Constitutional Court of the Russian Federation."

The Constitution establishes the division of powers between the federal and regional bodies. Thus, Article 71 establishes federal powers, and Article 72 joint powers of the Federation and its constituent entities. Let us first consider the additions made to Article 71 of the Constitution.

To begin with,"organization of public authority" is now referred to federal jurisdiction. This means that the federation has taken upon itself the issues of organization of both state and municipal authorities, since it is precisely these in the aggregate that is public authority. This provision conflicts with Article 12 of the Constitution, which stipulates that local authorities are not included in the system of state bodies. This caused a rather lively discussion in the legal scientific community. So, the chairman of the Constitutional Court V. Zorkin, even before the process of amending the Constitution began, wrote that the construction of Article 12 of the Constitution of the Russian Federation gives rise to the opposition of local governments to state bodies (including representative bodies of state power), while local governments by their nature are only the lower, local link of public authority in the Russian Federation. ${ }^{10}$

The federal jurisdiction now also includes: establishing the foundations of federal policy and federal programs in the field of scientific and technological development of the Russian Federation; the establishment of a unified legal framework for the healthcare system, the system of upbringing and education, including continuing education; ensuring the safety of individuals, society and the state in the application of information technology, the circulation of digital data; and metrological service.

10 Зорькин В.Д. Буква и дух Конституции - о тревожных призывах к кардинальным конституционным реформам // Российская газета. 9 октября 2018 г. [Valery D. Zorkin, The Letter and Spirit of the Constitution - On Alarming Calls for Radical Constitutional Reforms, Rossiyskaya Gazeta, 9 October 2018] (Sep. 16, 2020), available at https://rg.ru/2018/10/09/zorkin-nedostatki-v-konstitucii-mozhnoustranit-tochechnymi-izmeneniiami.html. 
In addition, now the federal jurisdiction has the right to establish restrictions for filling state and municipal posts, positions of state and municipal service, including restrictions related to the presence of citizenship of a foreign state or residence permit or other document confirming the right of permanent residence of a citizen of the Russian Federation on the territory of a foreign state, as well as restrictions related to the opening and availability of accounts (deposits), storage of cash and valuables in foreign banks located outside the territory of the Russian Federation. Such restrictions were established by federal laws; however, now this is enshrined in the Constitution of the Russian Federation.

The joint powers, as already noted, are enshrined in Article 72 of the Constitution, which was also supplemented by the following subjects, namely: agriculture; general issues of youth policy; ensuring the provision of affordable and high-quality medical care, maintaining and strengthening public health, creating the conditions for a healthy lifestyle, and creating a culture of responsible citizens' attitude to their health; protection of the family, motherhood, fatherhood and childhood; defending the institution of marriage as a union of a man and a woman; creation of conditions for a decent upbringing of children in the family, as well as for the fulfillment by adult children of the obligation to take care of their parents. It is easy to notice that at the constitutional level the institution of marriage is fixed, which is defined as the union of a man and a woman. Thus, the constitutional legislator, relying on the centuriesold traditions and cultural code of the Russian people, unlike many states that have liberalized their legislation in this area, allowing gay marriage, establishes, in fact, a constitutional ban on such marriages. Prior to this, the definition of marriage as a union of a man and a woman was contained in the Family Code, i.e. at the level of federal law.

For the first time, the Constitution mentions the highest official of a subject of the Russian Federation. Prior to this, his status was regulated by federal and regional laws. Now the Constitution establishes certain requirements and restrictions relating to the highest officials of the constituent entities of the Russian Federation. Article 77 was supplemented by the following provision:

The highest official of a subject of the Russian Federation (the head of the highest executive body of state power of a subject of the Russian Federation) may be a citizen of the Russian Federation who has reached the age of 30 years, has resided permanently in the Russian Federation and does not have citizenship of a foreign state or residence permit or other document confirming the right to permanent residence of a citizen of the Russian Federation in the territory of a foreign state. The highest official of a subject of the Russian Federation (the head of the highest executive body of state power of a constituent entity of the Russian Federation) is prohibited from opening and having accounts (deposits), storing cash and valuables in foreign banks located 
outside the territory of the Russian Federation in the manner established by federal law. Federal law may establish additional requirements for a highest official of a subject of the Russian Federation (head of the highest executive body of state power of a constituent entity of the Russian Federation).

That is, these restrictions are not exhaustive. Federal law may establish additional requirements for regional heads.

\section{Conclusion}

Federal relations reflect the essence and specificity of a particular federal system in terms of normative regulation of its parameters, establishing the status of its entities, including rights, duties and responsibilities. This kind of consolidation is carried out both at the time of the emergence of such relations, for example, the adoption of the Constitution or the conclusion of treaties and agreements between the federation and its constituent entities, and in the process of developing federal relations. Thus, the modern period is characterized by filling these relations with new constitutional content by virtue of the adoption of amendments to the Constitution of the Russian Federation. The expediency and operability of these amendments will be shown with the passage of time.

The current modern period is overshadowed by the situation with the global pandemic, which has also affected federal relations, moreover, not only in the Russian Federation, but also in other federations. This difficult situation shows that the federal center should trust the constituent entities of the Federation more and, accordingly, transfer to them the implementation of those powers that are advisable to be carried out precisely by the regional authorities. However, the transfer of powers alone cannot lead to the decentralization of the federal system itself. More dramatic steps are required, namely, reforming the tax system in order to provide greater financial opportunities to regions and municipalities. It is the principle of subsidiarity that should underlie the functioning of any federal system, if the goal is its sustainable development.

\section{Acknowledgements}

The research was supported by the Russian Foundation for Basic Research within the project No. 19-011-00697 "Rule of Law, Federalism and Protection of Human Rights: Comparative Study."

\section{References}

Elazar D.J. Exploring Federalism (Tuscaloosa, AL: University of Alabama Press, 1987). 
Frommeyer T.A. Power Sharing Treaties in Russia's Federal System, 21(1) Loyola of Los Angeles International and Comparative Law Review 1 (1999).

Halberstam D. Federalism: Theory, Policy, Law in The Oxford Handbook of Comparative Constitutional Law 576 (M. Rosenfeld \& A. Sajy (eds.), Oxford: Oxford University Press, 2012). https://doi.org/10.1093/oxfordhb/9780199578610.013.0029

King P. Federalism and Federation (Baltimore, MD: Johns Hopkins University Press, 1982).

Mandelker D.R. et al. State and Local Government in a Federal System ( $3^{\text {rd }}$ ed., Charlottesville, VA: The Michie Company, 1990).

Muravyeva M. The Quest for Constitutionalism in South Africa, 3(1) BRICS Law Journal 138 (2016). https://doi.org/10.21684/2412-2343-2016-3-1-138-143

Pechenskaya-Polishchuk M.A. Issues of Improving Inter-Budget Relations Between the Region and the Federal Centre, 6(24) Economic and Social Changes: Facts, Trends, Forecast 156 (2012).

Rishi dev Sharma P. Comparative Federalism with Reference to Constitutional Machinery Failure (Emergency) in India and Pakistan, 4(2) BRICS Law Journal 71 (2017). https://doi.org/10.21684/2412-2343-2017-4-2-71-94

Sadyrtdinov R.R. Interregional Trade Relations: The Republic of Tatarstan and Volga Federal District Regions of Russian Federation, 17(1) Journal of Economics and Economic Education Research 30 (2016).

Salikov M.S. Russian Federation Sub-National Constitutional Law (The Hague: Kluwer Law International, 2011).

Stewart W.H. Concepts of Federalism (Lanham, MD: University Press of America, 1984).

Watts R.L. Comparing Federal Systems in the 1990s (Kingston: Queen's University, 1997).

Zimmerman J.F. Contemporary American Federalism: The Growth of National Power (Westport, CT: Praeger Publishers, 1992).

\section{Information about the author}

Marat Salikov (Yekaterinburg, Russia) - Head of the Department of Constitutional Law, Ural State Law University (21 Komsomolskaya St., Yekaterinburg, 620137, Russia; e-mail: salikov.marat@list.ru). 